\title{
Effect of cultural conditions on biomass and nitrate reductase activity in six strains of anabaena isolated from paddy field soils of Ganjam (Orissa)
}

\author{
Padhi S.B.*, Behura S., Behera G., Behera S., Swain P., Panigrahi M., \\ Panigrahi H., Mishra A., Beja S., Baidya S. and Pradhan S.
}

Algal Research Laboratory, Department of Botany, Berhampur University, Bhanja, 760007, Bihar, sailabalapadhi@gmail.com, sasmitabehura@gmail.com

\begin{abstract}
Cyanobacteria offer an economically and ecologically sound alternative to chemical fertilizers for realizing the ultimate goal of increased productivity, especially in rice cultivation. There is however, a growing concern about the adverse effects of indiscriminate use of chemical fertilizers on soil productivity and environmental quality. A comparative study between the NR activity and biomass of six Anabaena strains isolated from paddy field soils of Ganjam district in presence of $\mathrm{pH}$, temperature, copper\& molybdenum, $\mathrm{NaNO}_{3}, \mathrm{NH}_{4} \mathrm{Cl}$, and Urea is being conducted to present a situation where $\mathrm{NR}$ activity and biomass may be affected under varied concentration. Maximum NR activity was observed in Anabaena sp. at pH 8.5 and $35^{\circ} \mathrm{C}$ temperature while Anabaena circinalis showed minimum activity in same concentration. Biomass content was maximum in Anabaena variabilis at $\mathrm{pH} 8.5$ where as at temperature $35^{\circ} \mathrm{C}$ in Anabaena flos-aquae and minimum biomass observed in Anabaena iyengarii at same concentration. NR activity in relation to copper was maximum in Anabaena sp. at $2 \square \mathrm{g} / \mathrm{l}$ while minimum in Anabaena circinalis at same concentration. At $0.5 \mu \mathrm{g} / \mathrm{l}$ molybdenum content in the culture medium showed maximum NR activity in Anabaena sp and reduced in all strains with increase of concentration. Anabaena flos-aquae showed minimum NR activity at $0.1 \mathrm{mM}$ concentration of $\mathrm{NaNO}_{3}$ while Anabaena circinalis showed minimum NR activity at same concentration of $\mathrm{NH}_{4} \mathrm{Cl}$. The $\mathrm{NR}$ activity was observed minimum at $3 \mathrm{mM}$ concentration of Urea in A. cylindrica. The activity of NR and biomass in all the strains was influenced by external $\mathrm{NH}_{4}$ and $\mathrm{NO}_{3}{ }^{+}$and Urea concentration.
\end{abstract}

Key Words: $\mathrm{pH}$, temperature, copper, molybdenum, $\mathrm{NaNO}_{3}, \mathrm{NH}_{4} \mathrm{Cl}$, Urea

\section{Introduction}

Cyanobacteria are gram-negative prokaryotes which flourish in rice paddy field and play a major role in sustaining the fertility of this ecosystem. Many cyanobacteria are their ability to fix atmospheric nitrogen both under free-living and symbiotic conditions, can used as biofertilizer in paddy fields of Ganjam District [25, 12]. The increasing use of synthetic nitrogen fertilizers in the agriculture created confusion regarding their on the nitrogen fixing activity of microorganisms. The effect of nitrogen fertilizers on alga Anabaena cylindrica was studied and concluded that (i) the addition of such fertilizers to the natural population of blue-green algae will affect the nitrogen fixation, and (ii) among the two types of fertilizers the depressive effect of ammonium nitrogen is likely to be more than the nitrate nitrogen [26]. Nitrate and ammonium are both potential sources of inorganic combined nitrogen for cyanobacteria under natural condition. Nitrate is currently one of the most hazardous pollutants $[2,4,11,28]$. NR is an enzyme that is being used to help cleanup the environment, by conversion of nitrate to nitrite and has great potential to be part of the solution to the global problem of excess nitrate and related nitrogen nutrients in water sources [5]. NR protein is responsible not only for nitrate reduction, but also for nitrate uptake in Chlamydomonas, Chlorella sorokiniana
$[15,19]$. Assimilatory $\mathrm{N}$ reduction, performed by a variety of bacteria and eukaryotic organisms [30, 27] includes the reduction of nitrate and nitrite compounds, often mediated by nitrate or nitrite reductase enzymes, for synthesis of amino acids. Nitrate reductase (NR) activity is the limiting factor when considering the growth and protein production of algae [17]. Nitrate reductase assays may prove to be important in algal ecology as the enzyme is suggested as an indicator of biomass $[3,7,8]$. However, the assays are more important in determining if the cells are assimilating $\mathrm{NO}_{3}$ or $\mathrm{NH}_{4}{ }^{+}$[7] or perhaps as a tool of measuring their rates of $\mathrm{NO}_{3}{ }^{-}$ assimilation [3]. The interpretation of $\mathrm{NO}_{3}{ }^{-}$ reductase activity in phytoplankton population should depend on a complete understanding of the factors which control the enzyme's synthesis, stability, inhibition or latency [20]. The effect of the nitrogen source on the cellular activity level of assimilatory nitrate reductase in the cyanobacteria Anabaena variabilis (ATCC29413) and Synechocystis sp. (PCC6714) has been examined [9]. Among soil properties of paddy field, $\mathrm{pH}$ is a very important factor in growth, establishment and diversity of cyanobacteria which have generally been reported to prefer neutral to slightly alkaline $\mathrm{pH}$ for optimum growth [14]. Soil pH is also known to have a selective effect on the indigenous algal flora, especially 
cyanobacteria and their succession and abundance in soil. Species of Anabaena are wide spread in Indian rice field soils and are known to contribute significantly to their fertility $[29,13$, and 18]. There are few reports on the existence of cyanobacteria at low $\mathrm{pH}$ (acidic range) as they are in general, intolerant to low $\mathrm{pH}$ conditions [1, 10, 6].

The present study deals with comparative account of the effect of different cultural conditions on biomass and nitrate reductase activity in six strains of Anabaena isolated from paddy field soils of Ganjam (Orissa). It also deals with the effect of excess addition of $\mathrm{N}$-source on the fertility of the paddy field.

\section{Material and Methods Anabaena Cultures}

Six strains of Anabaena were isolated from the water logged and dry paddy fields and made bacteria free. The bacteria free pure cultures of Anabaena employed in this investigation were Anabaena sp, Anabaena iyengarii, Anabaena cylindrica, Anabaena variabilis, Anabaena flosaquae, and Anabaena circinalis. They were grown in Kratz and Myer's medium with the trace elements, free from combined nitrogen and were maintained in sterilized cotton stopper conical flasks at temperature of $24 \pm 2^{\circ} \mathrm{C}$ in a culture room and illuminate with day light fluorescent tubes at an intensity of 2,200 lux [16]. The experiments were conducted by inoculation of algae (log phase filaments) into $25.0 \mathrm{ml}$. of culture medium in $100.0 \mathrm{ml}$. conical flasks. Triplicates were set up and the cultures were harvested at 4 days of intervals up to 20 days of incubation in presence of different concentration of $\mathrm{pH}$, temperature, nitrogen sources $\left(\mathrm{NH}_{4} \mathrm{Cl}, \mathrm{NaNO}_{3}, \quad\right.$ Urea), Molybdenum and Copper.

\section{Growth}

Growth was measured in terms of optical density at $760 \mathrm{~nm}$ with a Bausch and Lomb Spectronic20 spectrocolorimeter and converted into the corresponding dry weights as followed conventionally in this laboratory [24]. Specific growth rate constant was calculated with the dry weight results from the equation [16]:$$
\log (N / N o)
$$$$
\mathrm{K}=
$$$$
T
$$

Where $\mathrm{K}=$ Specific growth rate constant; $\mathrm{T}=$ days; $\mathrm{No}=$ Initial growth rate; $\mathrm{N}=$ Final growth rate.

\section{Estimation of Nitrate reductase}

Estimation of nitrate reductase activity in different strains of Anabaena at $\mathrm{pH}$, temperature and concentration of nitrogen source was determined by the colorimetric method of [30]. This depends upon the diazotization of an aromatic amino compound by nitrite in acid solution and coupling with a suitable reagent to give an intense purple colour. The cyanobacteria culture collected on a Millipore filter and washed with distilled water. The known amount of centrifuge algal material was suspended in $2.0 \mathrm{ml}$. of growth medium containing $0.02 \mathrm{~m} \mathrm{KNO}_{3}$ and incubated in light for period 24 hours. At the end of the incubation the following reagents were added.

Sulphanilamide ..............2.0ml

gm in $100.0 \mathrm{ml}$ of $1: 4 \mathrm{HCl}$ )

$\mathrm{N}$-(1-Napthine)-Ethylene diamine

Hydrochloride $0.2 \%$------------2.0ml

(0.2gm in $100 \mathrm{ml}$.of water)

The above solutions were mixed well. After 30 minutes, the solution was centrifuged and observance was measured 520nm in a VSU $2 \mathrm{P}$ Carizeiss Jena spectrophotometer. The amount of nitrite formed was calculated from the calibration curve of nitrite Vs Optical density, here $\mathrm{NaNO}_{2}$ was taken as the standard. The nitrate reductase activity was expressed $\mu \mathrm{g}$ nitrite / $\mathrm{mg}$ protein.

\section{Result}

Effects of various factors on Biomass and NR activity on six strains of Anabaena isolated from rice field were studied on $16^{\text {th }}$ days of incubation. Different species of Anabaena had shown differential responses to the different parameters. The figure from 1-12 shows the effect of nitrogen sources $\mathrm{NaNO}_{3}, \mathrm{NH}_{4} \mathrm{Cl}$ and Urea in the culture medium on the biomass and NR activity of different species of Anabaena. The significant increase of NR activity from 0.1 to $2 \mathrm{Mm}$ concentration of $\mathrm{NaNO}_{3}$ was observed in all employed strains of Anabaena. The increase in biomass at same concentration found in all strains of Anabaena except $A$. iyengarii. At $3 \mathrm{mM}$ concentration of $\mathrm{NaNO}_{3}$, the decreased of $\mathrm{NR}$ activity found in all strains but at same concentration decreased in biomass also found in A. sp., A. iyengarii, A. variabilis. From 0.1 to 2 $\mathrm{mM}$ concentration of $\mathrm{NH}_{4} \mathrm{Cl}$, the $\mathrm{NR}$ activity increase in $A$. sp., $A$. variabilis, and $A$. circinalis. At all concentration of $\mathrm{NH}_{4} \mathrm{Cl}$, both biomass and NR activity decreased in $A$. cylindrica where as inhibition started from $1 \mathrm{mM}$ onwards. The biomass decreased with increase of $\mathrm{NH}_{4} \mathrm{Cl}$ concentration from 0.1 to $2 \mathrm{mM}$ in $A$. sp., $A$. variabilis. In Anabaena flos-aquae \& A. circinalis, reduction of biomass observed from $1 \mathrm{mM}$ concentration onwards. Sudden decreased in biomass was observed at $2 \mathrm{mM}$ concentration in A. iyengarii but it again rise at $3 \mathrm{mM}$ concentration. The effect of Urea on biomass and $\mathrm{NR}$ activity shows significant growth from 0.1 to $2 \mathrm{mM}$ in $A$. sp, $A$. variabilis, $A$. flos-aquae and $A$. circinalis. The reduction of NR activity and biomass was observed at all concentration of Urea in A. cylindrica. In A. iyengarii, the reduction of NR activity and biomass was found from $1 \mathrm{mM}$ 
onwards. The NR activity in relation to copper \& molybdenum content of the culture medium in different strains of Anabaena on $16^{\text {th }}$ days of observation was illustrated in Fig (13) \& (14). The fig. (13) shows that the NR activity increased with increase in concentration of copper from 0.5 to 2 $\square \mathrm{g} / \mathrm{l}$. In $A$. circinalis, at $1.5 \square \mathrm{g} / \mathrm{l}$ concentration, the NR activity was observed with increase of molybdenum concentration from 0.5 to $2 \square \mathrm{g} / \mathrm{l}$ in all species of Anabaena. The effect of $\mathrm{pH}$ on biomass and NR activity of different species of Anabaena on $16^{\text {th }}$ days of incubation is analysed in Fig (15) \& (16). The increase in NR activity with increase in $\mathrm{pH}$ was observed in $A$. sp., $A$. cylindrica, $A$. variabilis. The NR activity decreased at $\mathrm{pH} 9.5$ in Anabaena iyengarii and in Anabaena circinalis it was at $\mathrm{pH}$ 8.5. From $\mathrm{pH} 5.5$ to 8.5 , the biomass of all strains of Anabaena increased. The biomass decreased from $\mathrm{pH} 8.5$ onwards where as in $A$. flos-aquae, it is at $\mathrm{pH}$ 8.5. Fig (17) \& (18) depicted the effect of temperature on biomass and NR activity. The result shows significant increase of biomass \& NR activity at $30^{\circ} \mathrm{C}$ in all strains of Anabaena. At $35^{\circ} \mathrm{C}$ in Anabaena sp, Anabaena flos-aquae and A. circinalis, both NR activity \& biomass decreased. The reduction NR activity observed at $35^{\circ} \mathrm{C}$ in Anabaena iyengarii, Anabaena variabilis and Anabaena cylindrica. The result of the experiment showed that higher concentration of cultural condition and nitrogen source affects the biomass and NR activity of six strains of Anabaena.

\section{Discussion and Conclusion}

In this investigation, the activity of $\mathrm{NO}_{3}{ }^{-}$reductase enzyme was influenced by external $\mathrm{NO}_{3}{ }^{-}, \mathrm{NH}_{4}{ }^{+}$ and Urea concentration. It is of interest that nitrate reductase in all the studied organisms is constitutive, since it is formed with $\mathrm{NH}_{4} \mathrm{Cl}$ and Urea in absence of nitrate, as the substrate. Ammonia and Urea do not depress the formation of nitrate reductase activity in all the species. However, the activity of nitrate reductase differs in different species. Similar results were obtained with different nitrogen sources on growth rate (biomass) of the studied organisms. Different species of Anabaena shows differential response to different concentration of molybdenum and copper. The decrease in enzyme activity may be due to a cessation of protein synthesis in the cells with the concomitant decay of the unstable nitrate reductase enzyme. The range of condition under which NR activity can be used to measure in situ growth rate of algal organism is severely restricted. Some of the $\mathrm{N}$ source that the cells are in vigorous growth stage, enzyme assayed represents the only NR activity pathway of the cell, and that are known the efficiency of enzyme.
A salient inverse correlation between NR activity and the division rate of Thalassiosira pseudonans (Hustedt) in an N-limited chemostats was reported [7]. Growth rate and enzyme activity paralleled each other which agree with the concept that both the processes are related. The enzyme is present and stable in the presence of $\mathrm{NH}_{4}{ }^{+}$and Urea. Nitrate reductase and growth rate of all the species of Anabaena were inextricably linked.

\section{Acknowledgement}

The authors express their deep sense of gratitude to Head, P.G. Department of Botany, and Berhampur University for laboratory facilities.

\section{References}

[1] Aiyer R. S. (1965) Agricultural Research Journal of Kerala, 3 (1), 100-104.

[2] Awasthi M. and Rai L. C. (2005) Environ. Safe. 61, 268-272.

[3] Balsco D. and Packard T. T. (1974) Tethys. 6, 239-46.

[4] Bier J. (2002) $6^{\text {th }}$ Symposium on Ground Water Contaminants, Nov $12^{\text {th }}$ and $13^{\text {th }}$ Frensco, CA.

[5] Campbell E. R. and Campbell W. H. (1998) In: Current protocols in field analytical chemistry, Supplement 1, Chapter 5 "Water Quality ParametersAnions", John Wiley and sons, Inc.

[6] Dominic T. K. and Madhusoodanan, P.V. (1999) Current Science, 77 (8), 1021-1022.

[7] Eppley R. W. and Renger E. H. (1974) Limnol.Oceanogr, 14, 194-205.

[8] Harrison W. G. (1973) Limnol.Oceanogr, 18, 457-65.

[9] Herrera J., Paneque A., Maldonado J., Barea J. I. and Losada M. (1973) Biochem, Biophysics. Res. Comm- 48, 996-1003

[10] Hunt M. E., Floyd G. L. and Stout, B. B. (1979) Ecology, 60 (2), 362-375.

[11] Johnson C. J. and Kross B. C. (1990) Am. J. Int. Med., 18, 449-456.

[12] Kannaiyan S. 1985. Studies on the Algal Application for Low Land Rice Crop. Coimbatore: T NAU, Tamil Nadu, India. p. 24.

[13] Kaushik B. D. (1991) Current Trends in Limnology, Vol. 1. Narendra publishing House, New Delhi.

[14] Kaushik B. D. (1994) Annales of Agricultural Research, 14, 105-106.

[15] Knobloch O. and Tischner R. (1989) Plant Physiol, 89, 786-791.

[16] Kratz W. A. and Myers J. (1955) Am. J. Bot. 42, 282-287. 
[17] Lau P. S., Tam N. F. Y. and Wong Y.S. (1998) Bioresource Technol., 63, 115121.

[18] Nayak S., Prasanna R., Dominic, T. K. and Singh P. K. (2004) Biology and Fertility of Soils, 40, 67-72.

[19] Nichols G. L., Snehata S. A. M. and Syrett P. J. (1978) J. Gen. Microbiol, 108, 79-88.

[20] Packard T.T. (1973) Limnol. Oceanogr, 18, 466-9.

[21] Padhi S. B. (1983) Ph.D. Thesis. Berhampur University.

[22] Singh P. K. (1975) Phykos, 14, 81-88.

[23] Singh P. K. (1976b) Biochem. Physiol. Pflanzen, 170, 237-242.

[24] Snell P.D. and Snell C.T. (1949) In Colorimetric Methods of Analysis .III Ed.2.804-805.D. Von Nostrand Company Inc., Princeton, New Jersey and New York.
[25] Stainer R.Y. and Cohen-Bazire G. (1977) Ann. Rev. Microbiol, 31, 225274.

[26] Stewart, W.D.P., Haystead A. and Dharmawardene (1975b) In: Stewart, W.D.P. (Ed.) : Nitrogen fixation be freeliving micro-organisms. IBP, 6, 129-158.

[27] Solomonson L. P. and Barber M. J. (1990) Plant Mol. Biol., 41, 225- 253.

[28] US Environmental Protection Agency (1987) Nitrate/ Nitrite health advisory. Washington: US Environmental protection Agency, Office of Drinking Water.

[29] Venkataraman G. S. (1981) Blue-Green Algae for rice production- a manual for its promotion- FAO Soils bulletin no. 46. FAO, Rome.

[30] Zvyagil'skaya R. A., Vartapetyan B. B. and Vov N. P. L. (1996) Appl. Biochem. Microbiol. 32, 165- 169. 
Padhi SB, et al

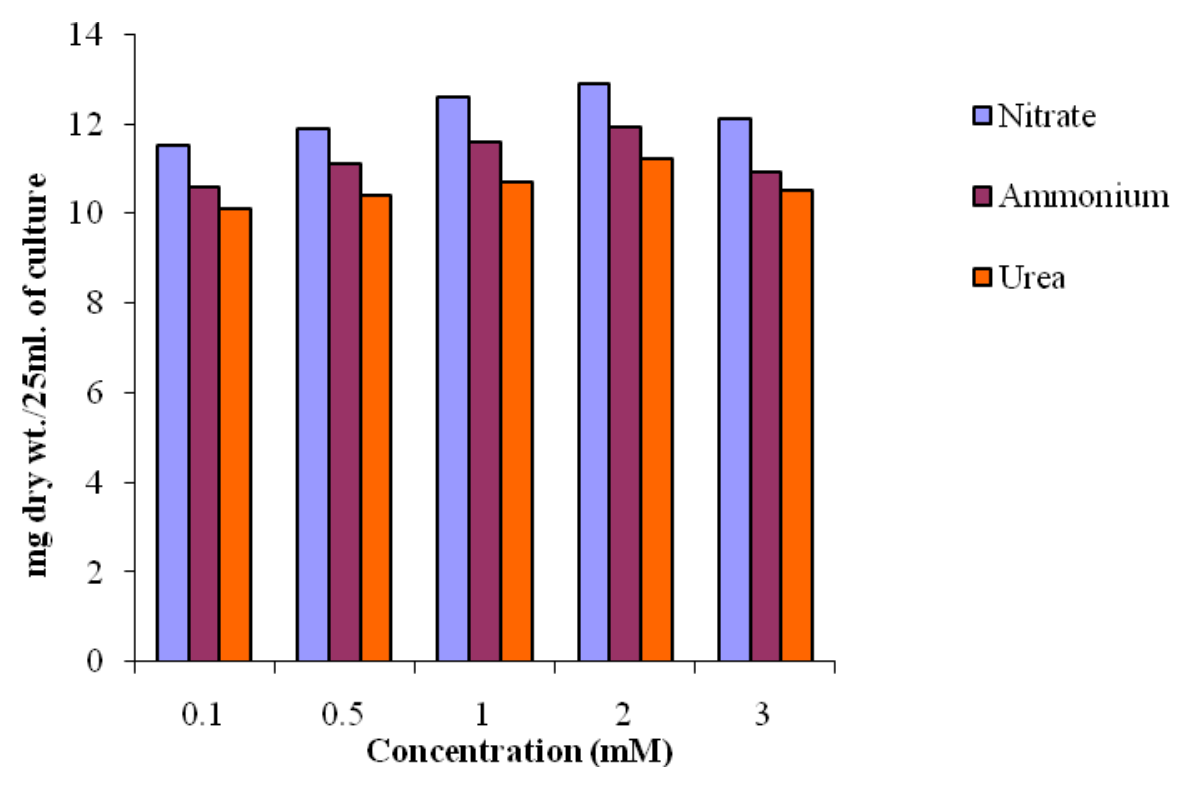

Fig. 1- Biomass of Anabaena sp. in relation to the nitrogen source in the culture medium $\left(\mathrm{KNO}_{3}, \mathrm{NH}_{4} \mathrm{Cl}\right.$, Urea) on 16 th days of observation (mg dry wt. $/ 25 \mathrm{ml}$. of culture)

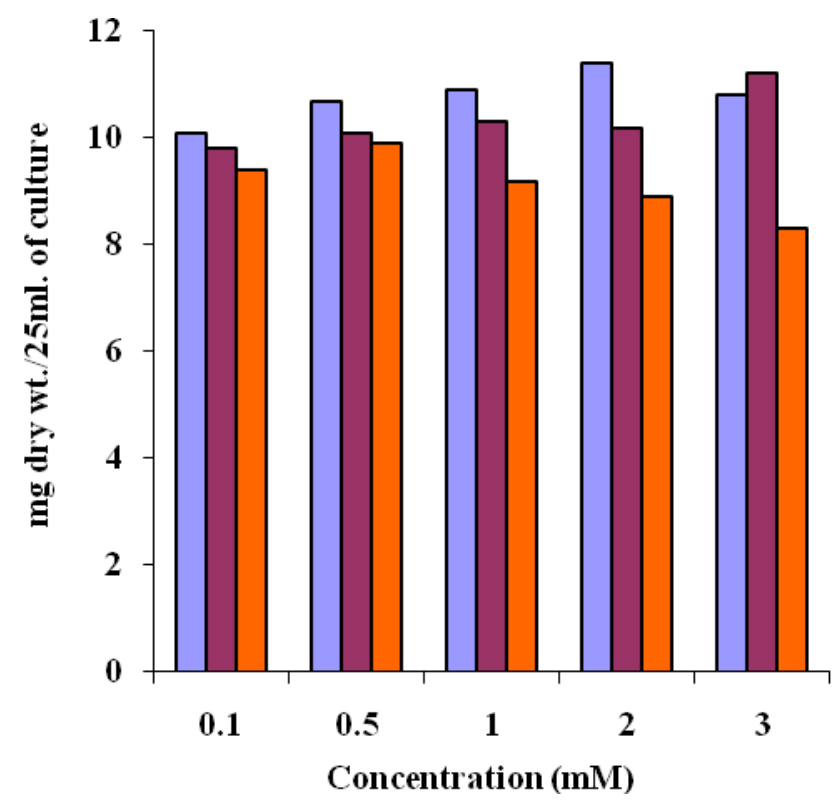

口Nitrate

口Ammonium

口Urea

Fig. 2-Biomass of Anabaena iyengarii in relation to the nitrogen source in the culture medium $\left(\mathrm{KNO}_{3}, \mathrm{NH}_{4} \mathrm{Cl}\right.$, Urea) on 16 th days of observation (mg dry wt. $/ 25 \mathrm{ml}$. of culture) 


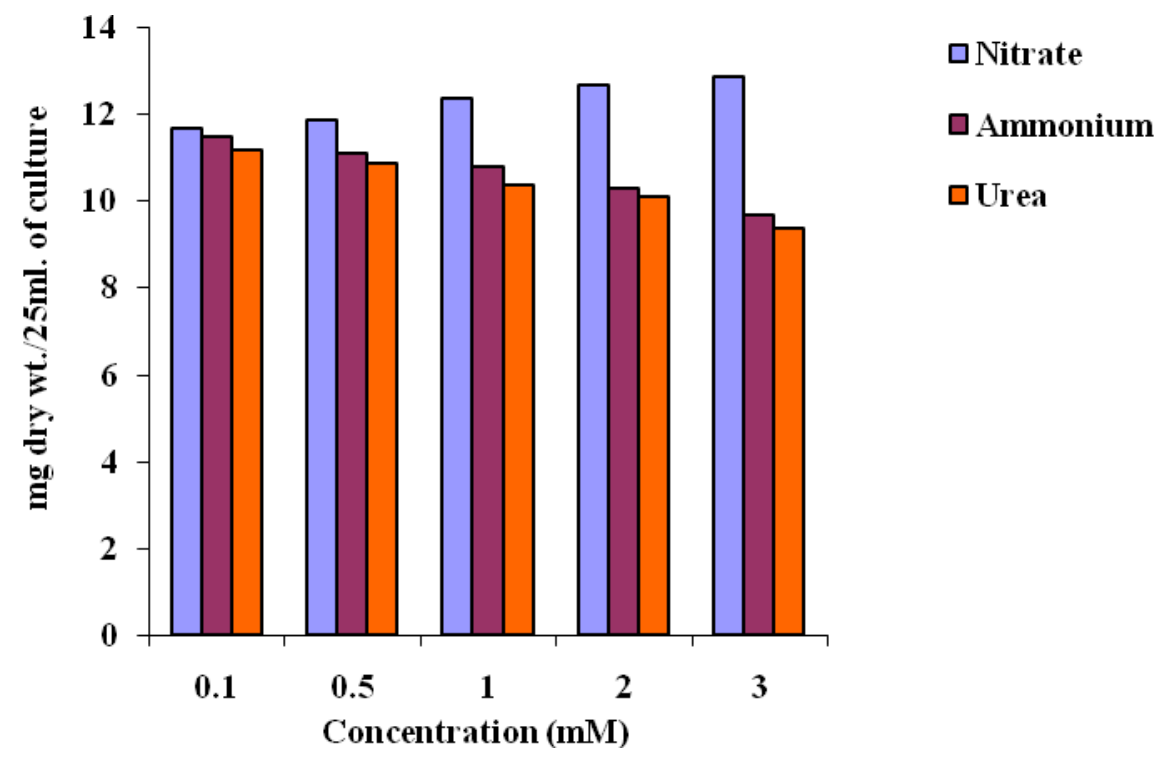

Fig. 3-Biomass of Anabaena cylindrica in relation to the nitrogen source in the culture medium $\left(\mathrm{KNO}_{3}\right.$, $\mathrm{NH}_{4} \mathrm{Cl}$, Urea) on 16 th days of observation (mg dry wt. $/ 25 \mathrm{ml}$. of culture)

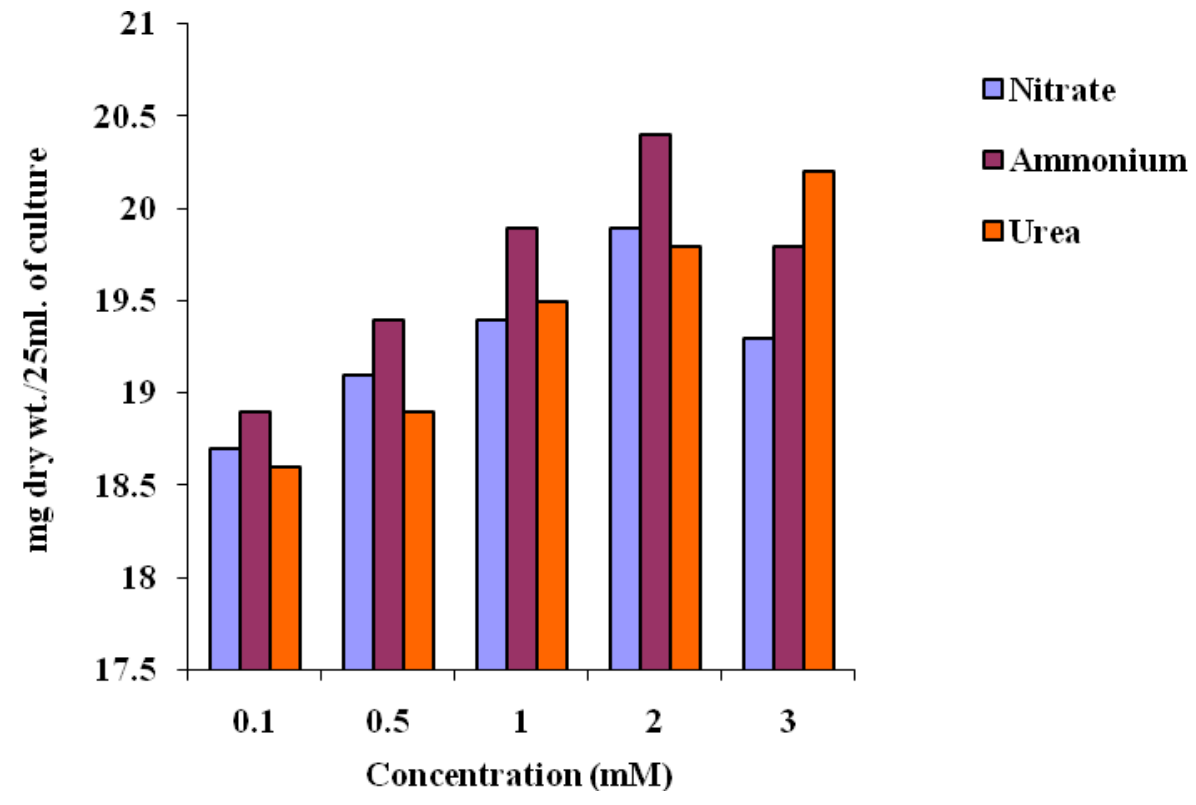

Fig. 4-Biomass of Anabaena variabilis in relation to the nitrogen source in the culture medium $\left(\mathrm{KNO}_{3}, \mathrm{NH}_{4} \mathrm{Cl}\right.$, Urea) on 16 th days of observation (mg dry wt. $/ 25 \mathrm{ml}$. of culture) 


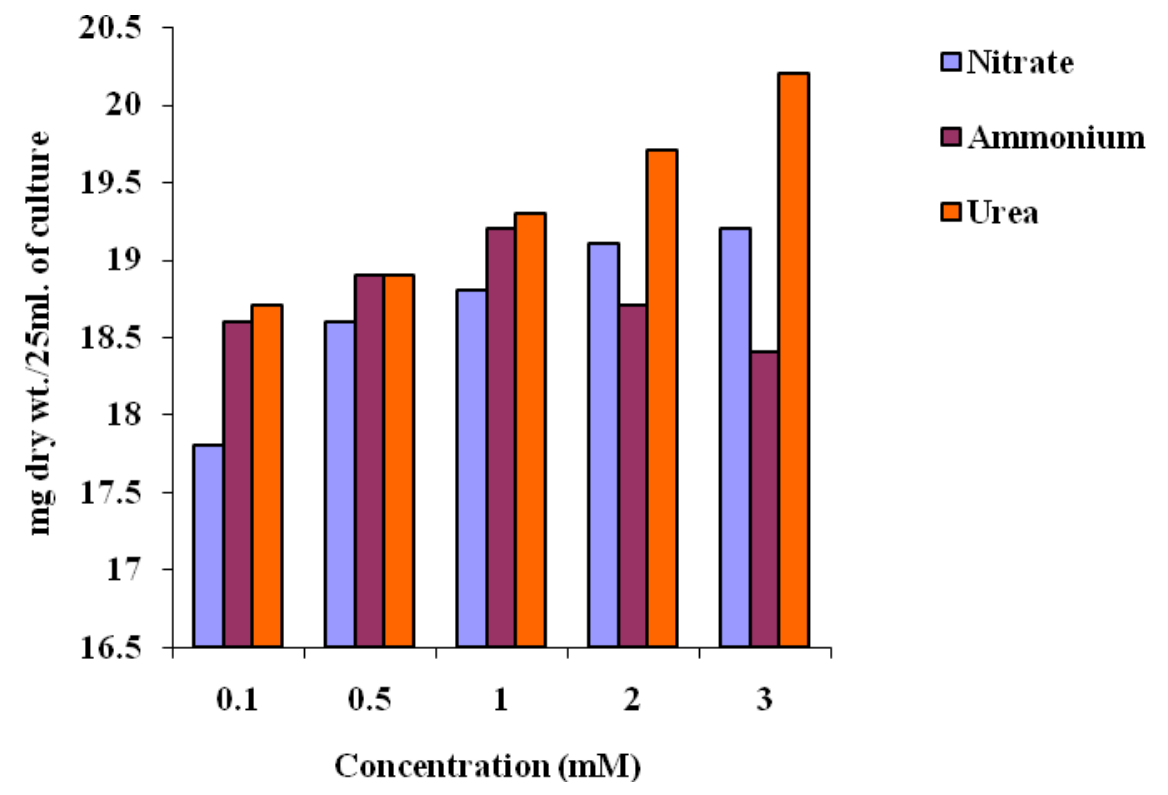

Fig. 5-Biomass of Anabaena flos-aquae in relation to the nitrogen source in the culture medium $\left(\mathrm{KNO}_{3}\right.$, $\mathrm{NH}_{4} \mathrm{Cl}$, Urea) on 16 th days of observation (mg dry wt. $/ 25 \mathrm{ml}$. of culture)

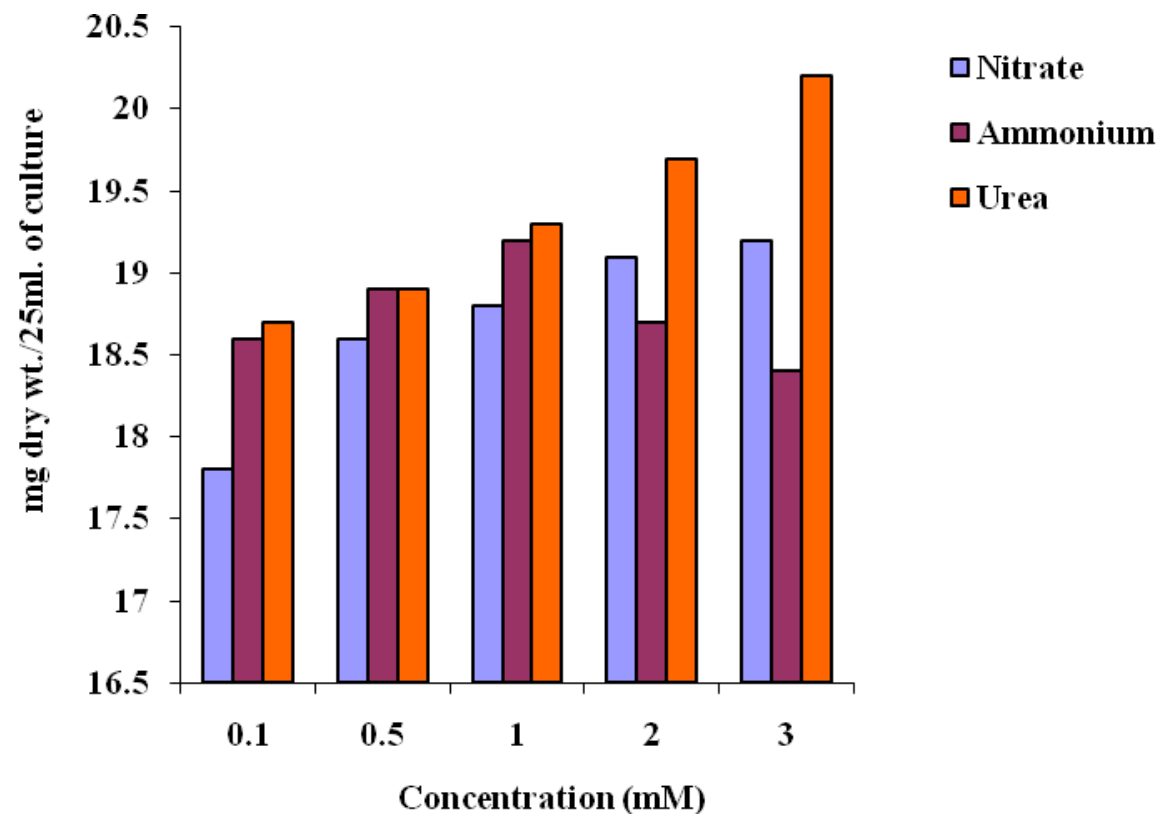

Fig. 6-Biomass of Anabaena variabilis in relation to the nitrogen source in the culture medium $\left(\mathrm{KNO}_{3}, \mathrm{NH}_{4} \mathrm{Cl}\right.$, Urea) on 16 th days of observation (mg dry wt. $/ 25 \mathrm{ml}$. of culture) 


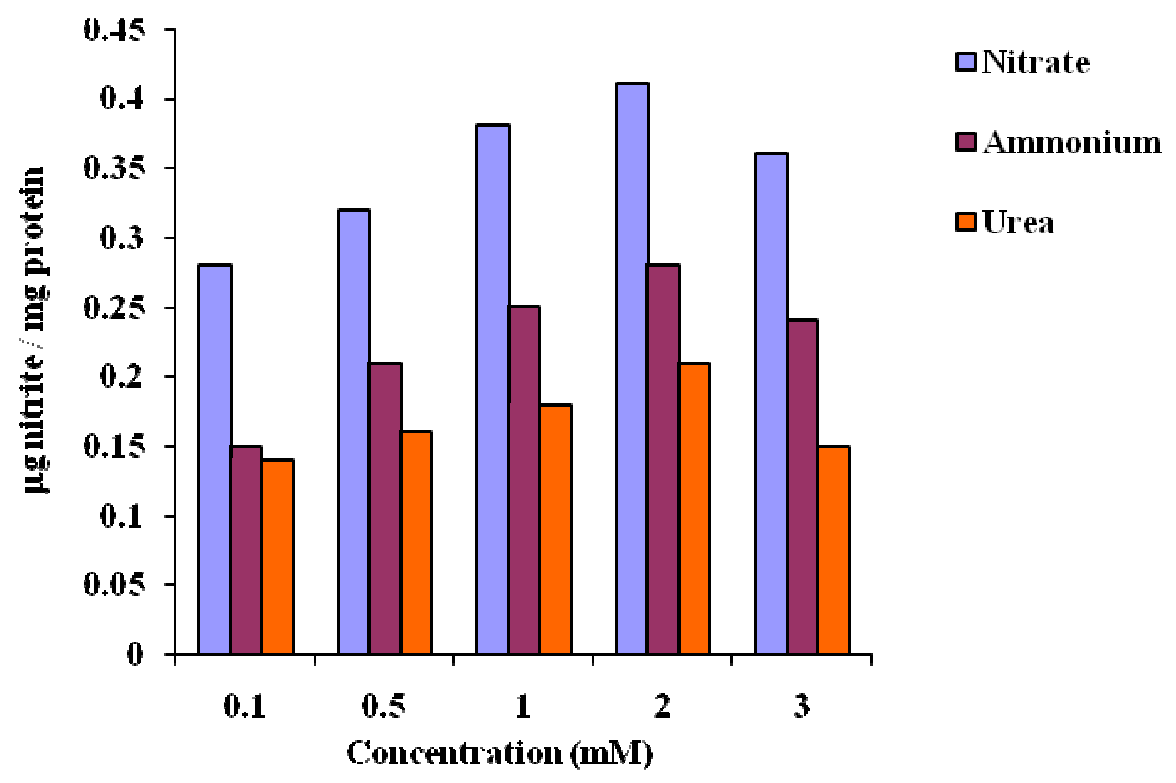

Fig. 7-Nitrate reductase activity of Anabaena sp. in relation to the nitrogen source in the culture medium $\left(\mathrm{KNO}_{3}, \mathrm{NH}_{4} \mathrm{Cl}\right.$, Urea) on 16th days of observation ( $\square \mathrm{g}$ nitrate / $\mathrm{mg}$ protein)

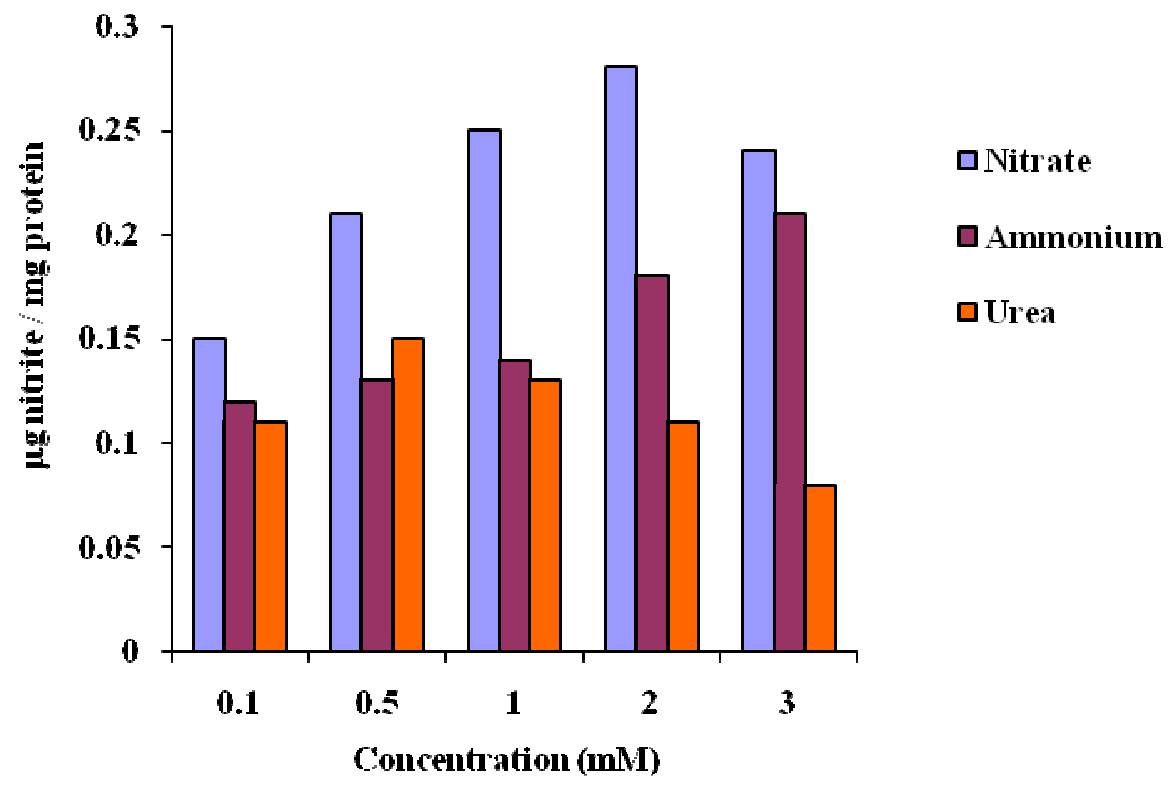

Fig. 8-Nitrate reductase activity of Anabaena iyengarii in relation to the nitrogen source in the culture medium $\left(\mathrm{KNO}_{3}, \mathrm{NH}_{4} \mathrm{Cl}\right.$, Urea) on 16th days of observation ( $\square \mathrm{g}$ nitrate / $\mathrm{mg}$ protein) 


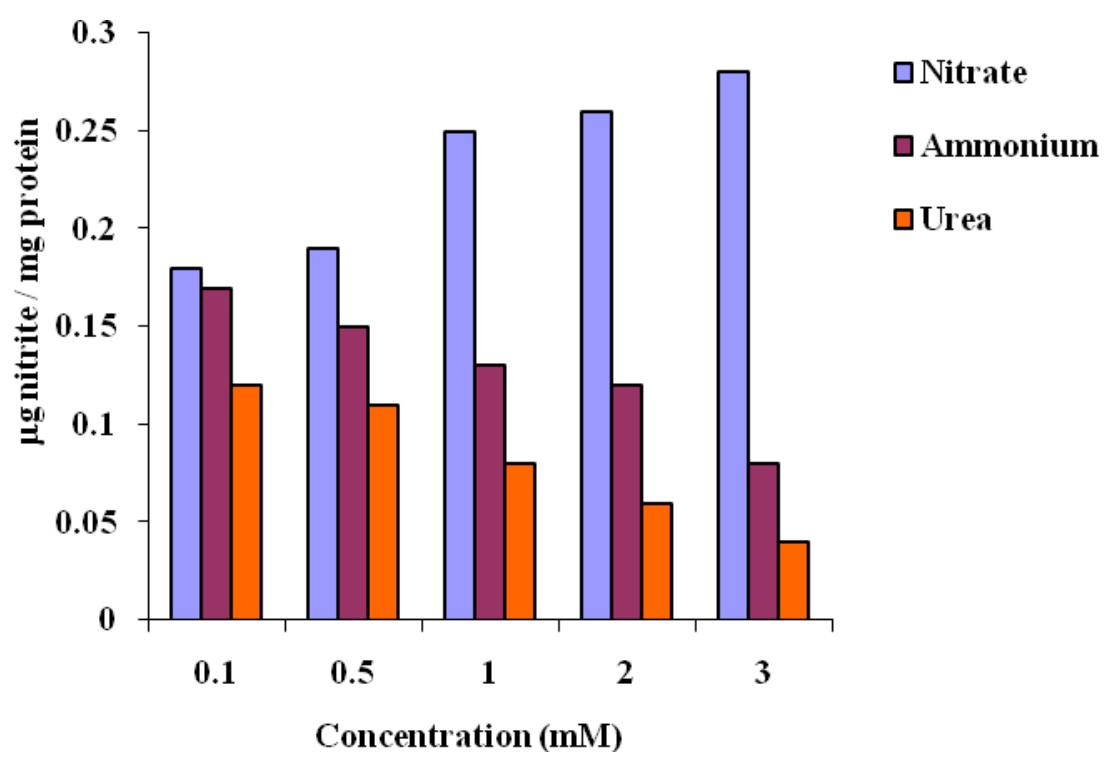

Fig. 9-Nitrate reductase activity of Anabaena cylindrica in relation to the nitrogen source in the culture medium $\left(\mathrm{KNO}_{3}, \mathrm{NH}_{4} \mathrm{Cl}\right.$, Urea) on 16th days of observation ( $\square \mathrm{g}$ nitrate / $\mathrm{mg}$ protein)

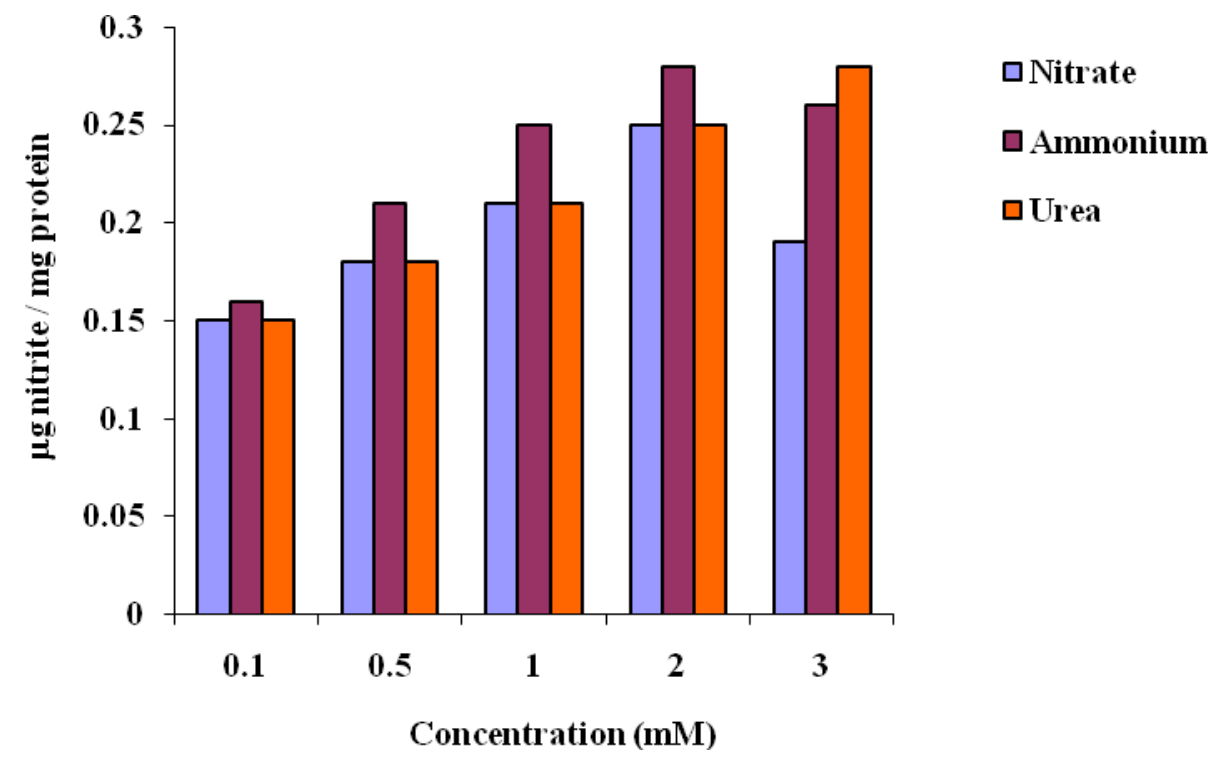

Fig. 10-Nitrate reductase activity of Anabaena variabilis in relation to the nitrogen source in the culture medium $\left(\mathrm{KNO}_{3}, \mathrm{NH}_{4} \mathrm{Cl}\right.$, Urea) on 16th days of observation ( $\square \mathrm{g}$ nitrate / $\mathrm{mg}$ protein) 


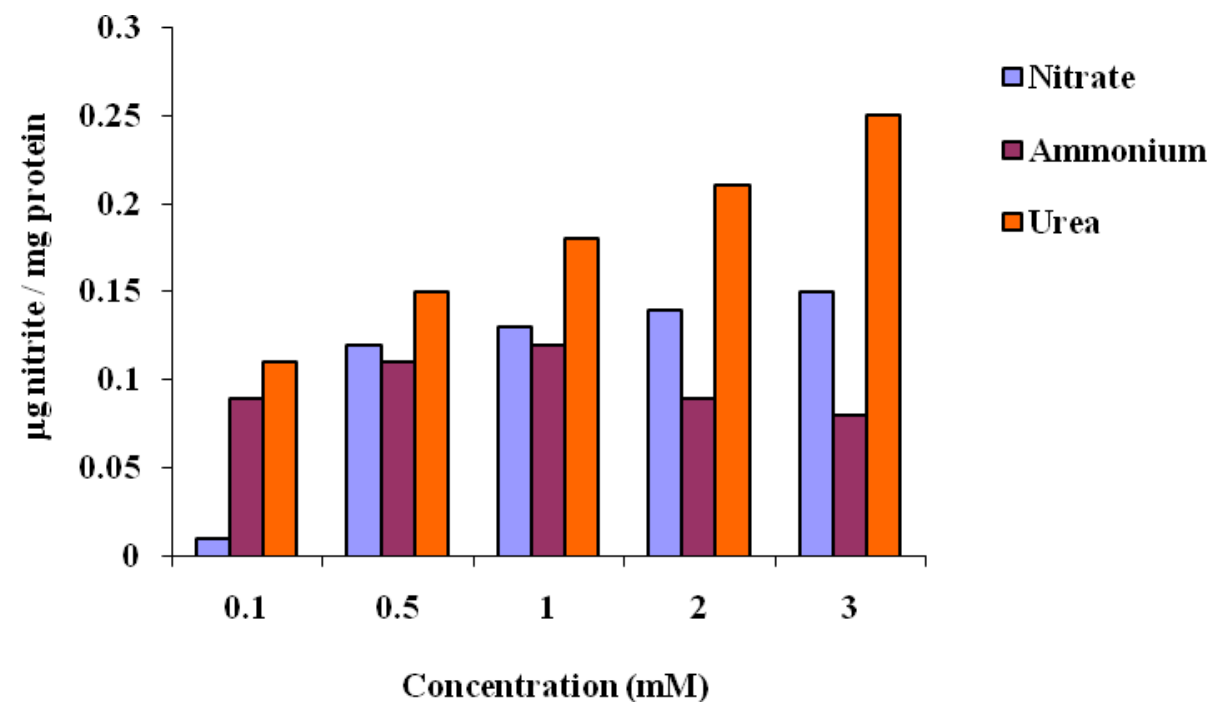

Fig. 11-Nitrate reductase activity of Anabaena flos-aquae in relation to the nitrogen source in the culture medium ( $\mathrm{KNO}_{3}, \mathrm{NH}_{4} \mathrm{Cl}$, Urea) on 16th days of observation ( $\square \mathrm{g}$ nitrate / mg protein)

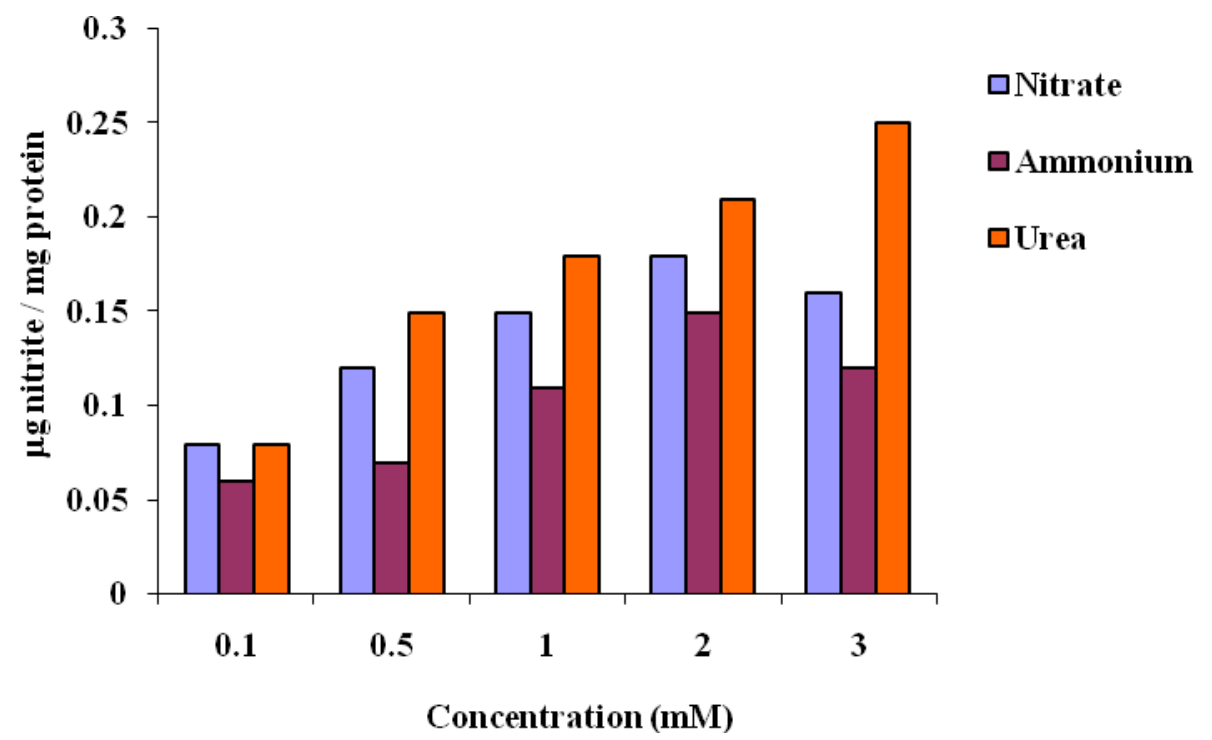

Fig. 12-Nitrate reductase activity of Anabaena circinalis in relation to the nitrogen source in the culture medium $\left(\mathrm{KNO}_{3}, \mathrm{NH}_{4} \mathrm{Cl}\right.$, Urea) on 16th days of observation ( $\square \mathrm{g}$ nitrate / $\mathrm{mg}$ protein) 


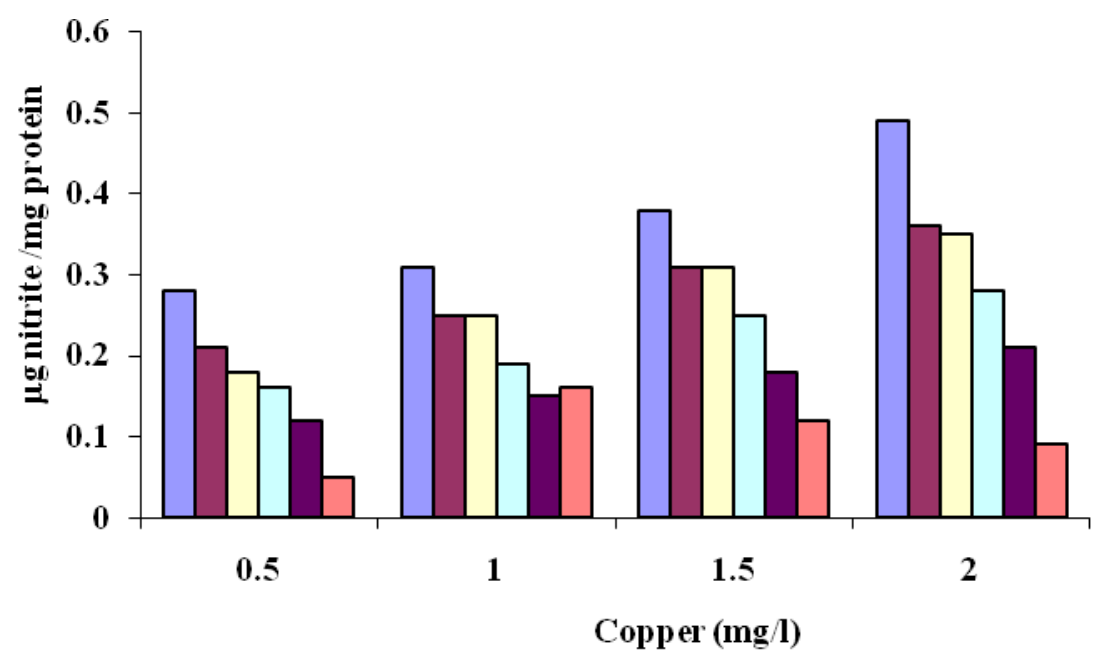

\section{a Anabaena sps. $\quad \square$ Anabaena iyengarii $\square$ Anabaena cylindrica \\ $\square$ Anabaena variabilis $\square$ Anabaena flos-aquae $\square$ Anabaena circinalis}

Fig. 13-Nitrate reductase activity in relations to copper content of the culture medium in different strains of Anabaena on 16 th days of observation ( $\square \mathrm{g}$ nitrate / $\mathrm{mg}$ protein)

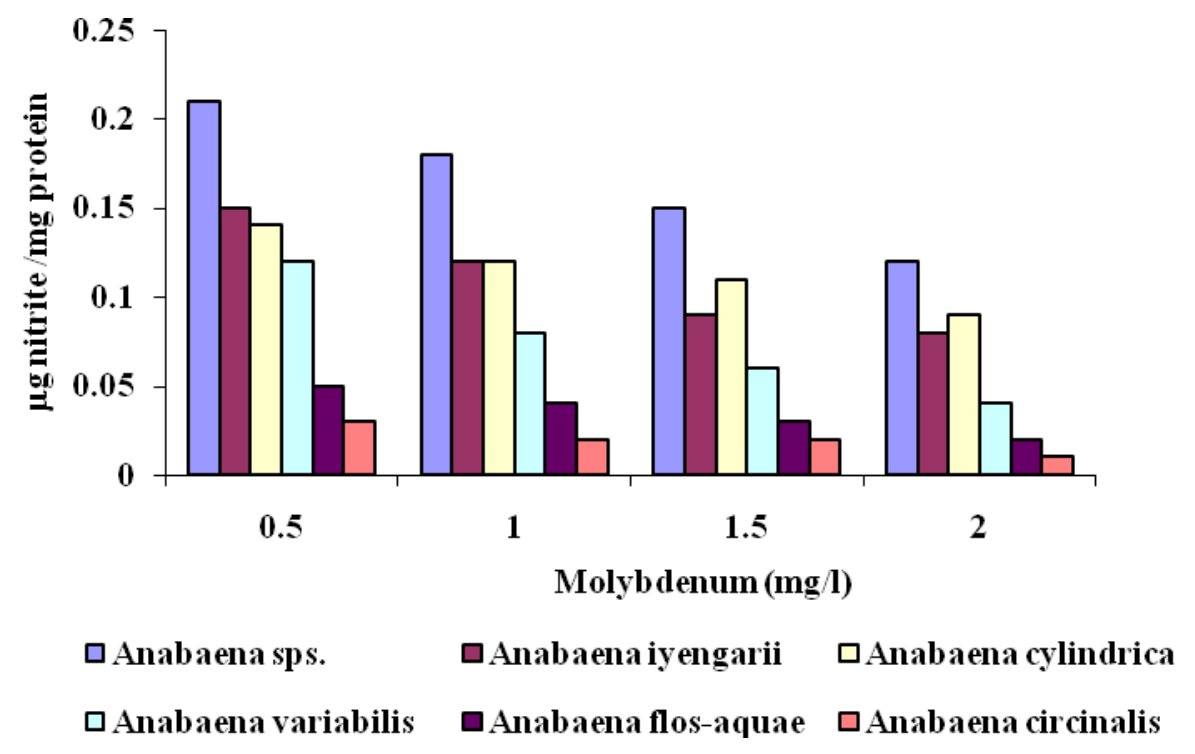

Fig. 14-Nitrate reductase activity in relations to molybdenum content of the culture medium in different strains of Anabaena on 16th days of observation ( $\square \mathrm{g}$ nitrate / $\mathrm{mg}$ protein) 


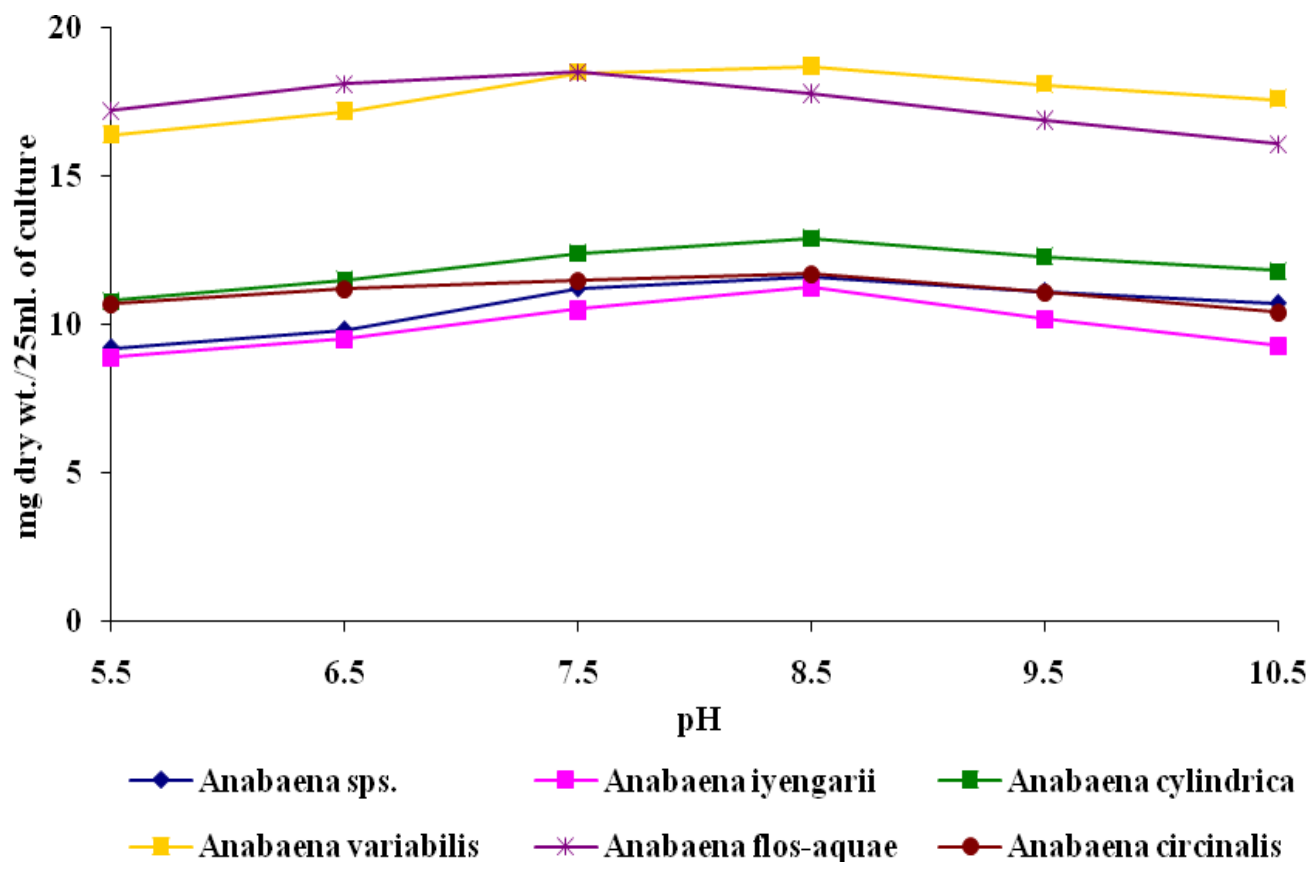

Fig. 15-Effect of pH on Biomass in different strains of Anabaena on 16th days of observation (mg dry wt. $/ 25 \mathrm{ml}$. of culture)

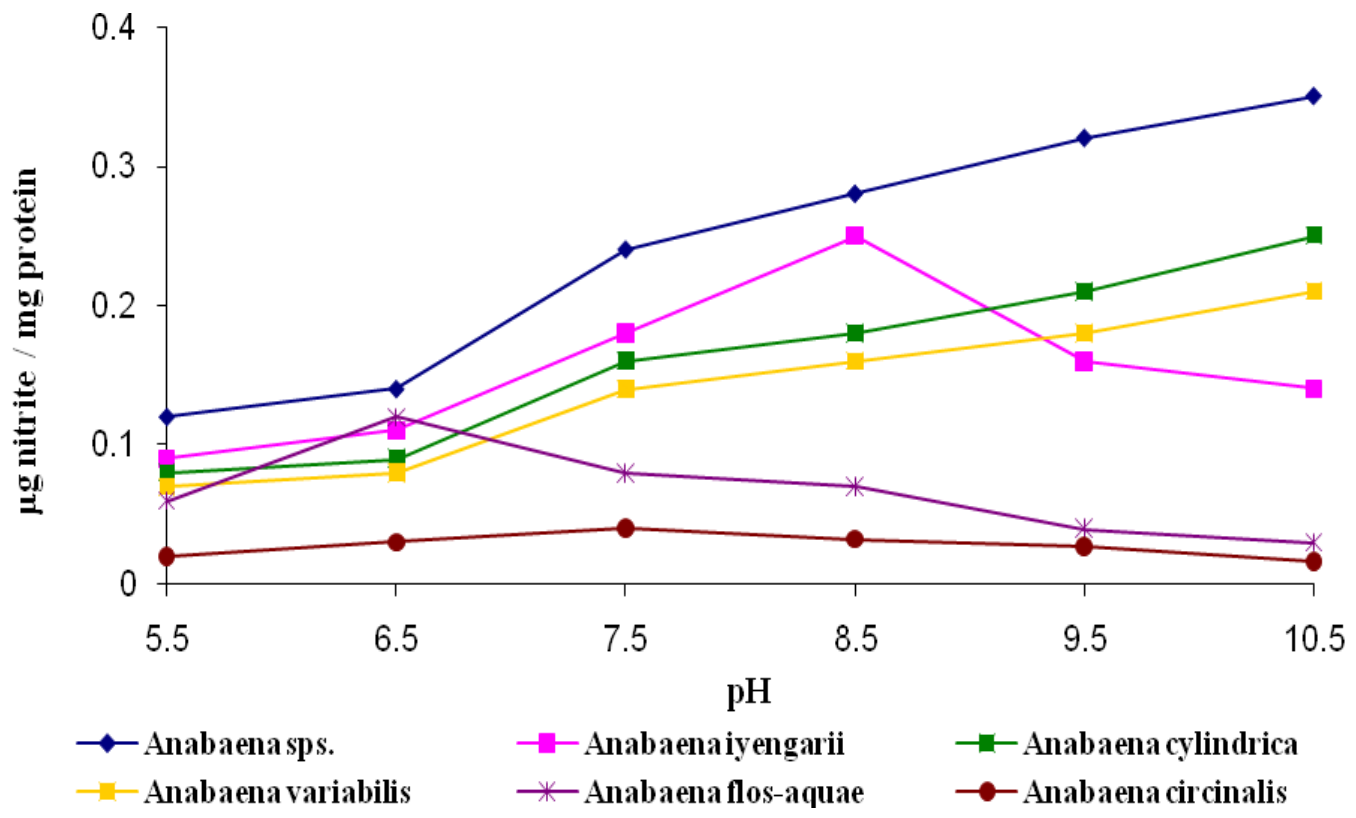

Fig. 16-Effect of pH on Nitrate reductase activity in different strains of Anabaena on 16th days of observation ( $\square \mathrm{g}$ nitrate / $\mathrm{mg}$ protein) 


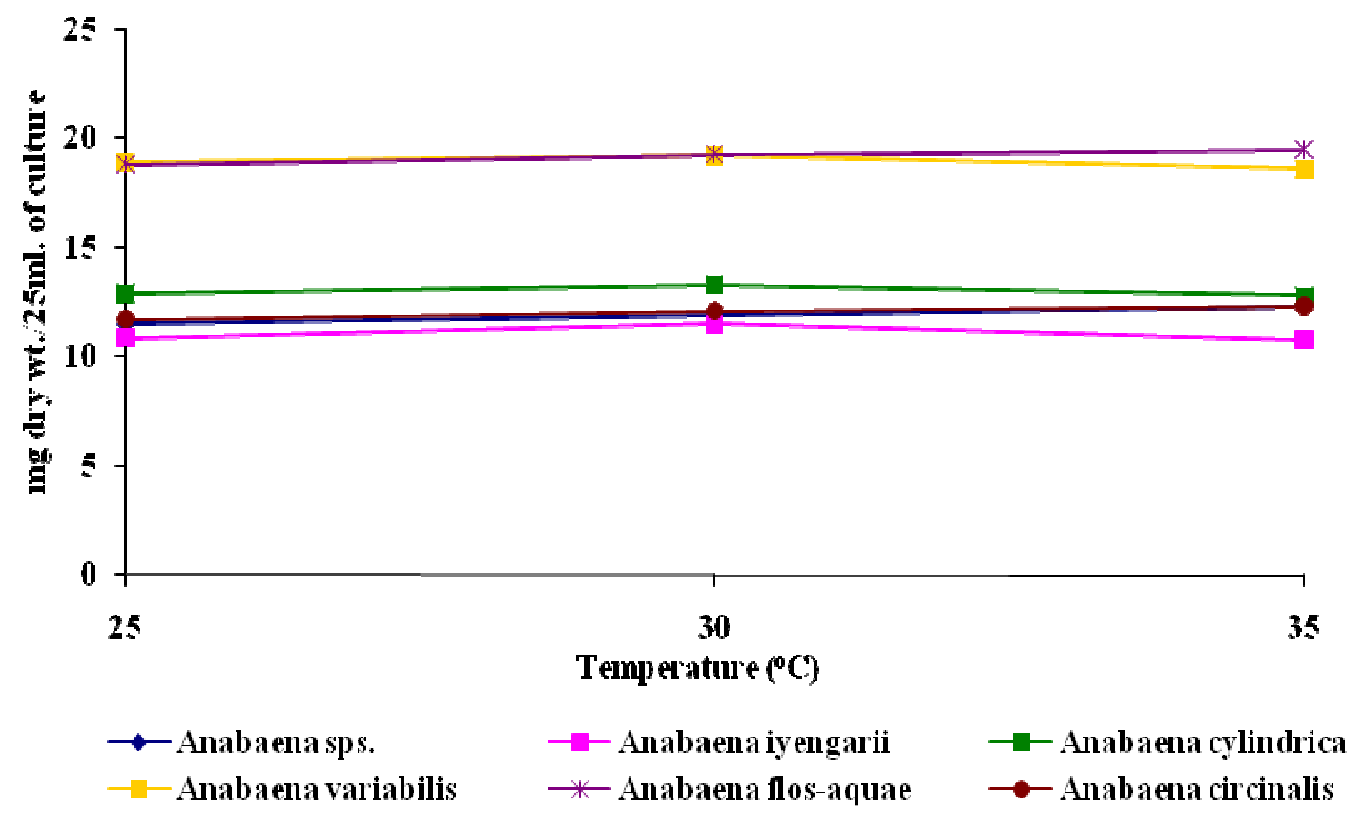

Fig. 17-Effect of Temperature on Biomass in different strains of Anabaena on 16th days of observation (mg dry wt. $/ 25 \mathrm{ml}$. of culture)

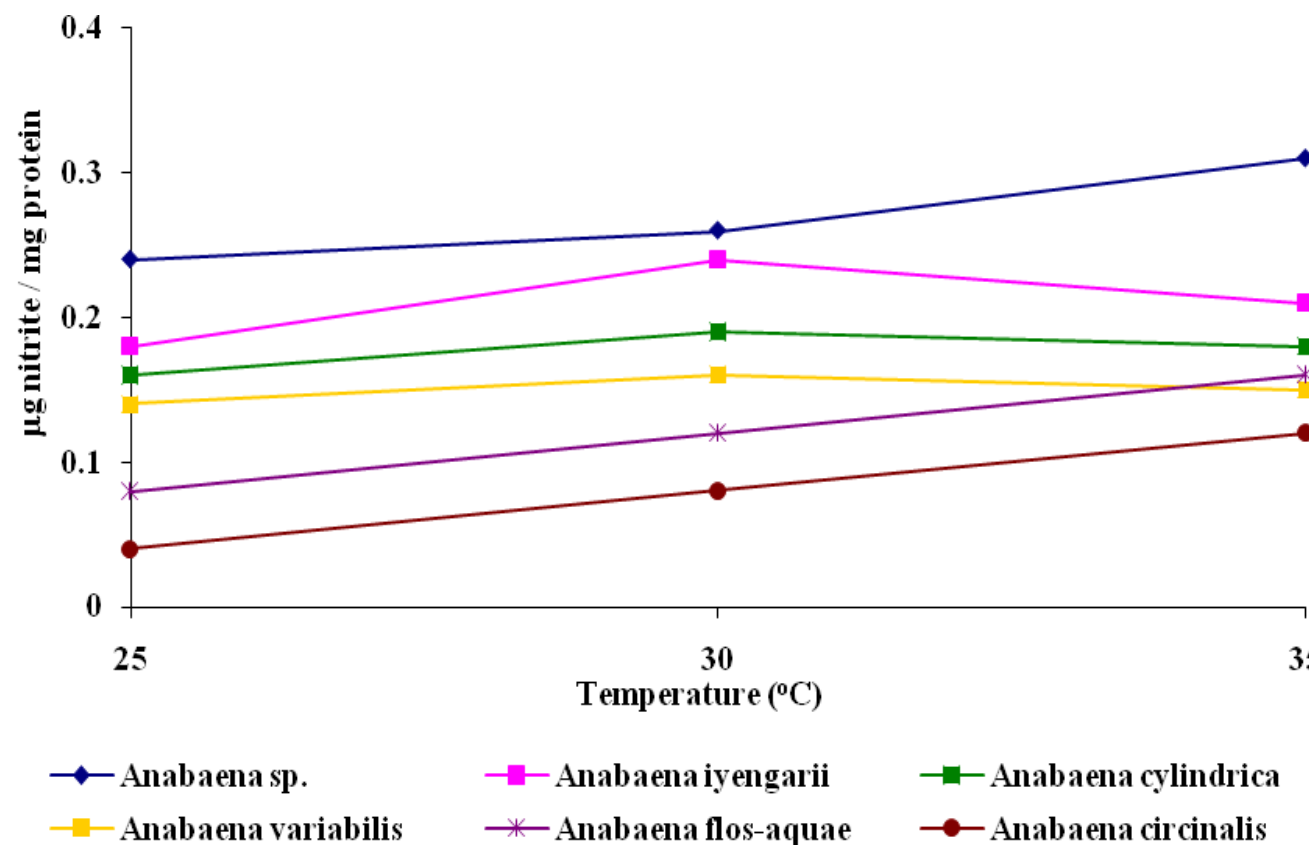

Fig. 18-Effect of Temperature on Nitrate reductase activity in different strains of Anabaena on 16th days of observation ( $\square \mathrm{g}$ nitrate / mg protein) 